Official languages: English, French.

Headquarters: 01 BP 1387, Abidjan 01, Côte d'Ivoire.

Website: http://www.afdb.org

e-mail:afdb@afdb.org

President: Omar Kabbaj (Morocco).

\title{
BANK OF CENTRAL AFRICAN STATES (BEAC)
}

The Bank of Central African States (Banque des Etats de l'Afrique Centrale) was established in 1973 when a new Convention of Monetary Co-operation with France was signed. The five original members, Cameroon, Central African Republic, Chad, Republic of the Congo and Gabon, were joined by Equatorial Guinea in 1985. Under its Convention and statutes, the BEAC is declared a 'Multinational African institution in the management and control of which France participates in return for the guarantee she provides for its currency'.

Official language: French.

Headquarters: Avenue Monseigneur Vogt, Yaoundé, Cameroon.

Website: http://www.beac.int

Governor: Jean-Félix Mamalepot.

Publications. Etudes et Statistiques (monthly bulletins); Annual Report; Directory of Banks and Financial Establishments of BEAC Monetary Area (annual); Bulletin du Marché Monétaire (monthly bulletins); Annual Report of the Banking Commission.

\section{EAST AFRICAN DEVELOPMENT BANK (EADB)}

Established originally under the Treaty for East African Co-operation in 1967 with Kenya, Tanzania and Uganda as signatories, a new Charter for the Bank (with the same signatories) came into force in 1980. Under the original Treaty the Bank was confined to the provision of financial and technical assistance for the promotion of industrial development in member states but with the new Charter its remit was broadened to include involvement in agriculture, forestry, tourism, transport and the development of infrastructure, with preference for projects which promote regional co-operation.

Official language: English.

Headquarters: 4 Nile Avenue, Kampala, Uganda.

Website: http://transafrica.org/eadb/

Chairman of the Board: Mwaghazi Mwachofi (Kenya).

\section{WEST AFRICAN DEVELOPMENT BANK (BOAD)}

The West African Development Bank (Banque Ouest Africaine de Développement) was established in Nov. 1973 by an Agreement signed by the member states of the West African Monetary Union (UMOA), now the West African Economic and Monetary Union (UEMOA). 